\title{
CHICKADEES
}

DAVID G. MILLER, 515 Gabriel Road, Grasswood, SK. S7T 1A9

This is the original of the article that was adapted for "Nature Notes" in the Saskatoon Sun.

My wife's crazy. Well, a bit unrealistic, anyway. It's not her fault, really, city-born and an Easterner, Cathryn has made admirable progress since we settled near Saskatoon. The way she shakes her head at rainless skies and damns the railroads, you'd never guess she was born in Toronto. It's in matters concerning the birds that she shows she's not quite in touch with reality, so when a very bold bunch of chickadees began to visit our feeder ten years ago and she announced, "I want them to sit on my finger," my response was a patronizing smile and a confident, rational prediction of failure.

Undaunted, Cathryn chose a morning in February when the chickadees had emptied the feeding station, and stationed herself beneath the feeder with an outstretched bare hand ("I want to feel their toes") full of sunflower seeds. And there she stood.

From time to time I glanced pityingly at her through my workshop window and wondered how long this futile foolishness would last; it was not a cold day for February, but it was February. The chickadees chirped their displeasure from the tree above her, and checked the feeder bowl. with increasing indignation. Cathryn's shivering was visible from the far side of the yard.

Forty-five minutes had passed; I had given up waiting for her to give up, and was concentrating on my wood-work, when the door of the shop burst open and my red-nosed spouse announced through chattering teeth, "Chickadees are so small they don't weigh anything when they land on your finger!" She was right, and when I finally got a turn at feeding them, I found the pinch of tiny claws enthralling, and the apparent weightlessness of the little black and grey fluff-balls a source of wonder and delight.

We had two regular chickadees that winter, and came quickly to distinguish them by behaviour - Brash was always the first in when called, flying straight to the proffered hand, picking over the seeds at leisure, and then flying off with the two largest ones he could find. Buddy was more hesitant, always landed on a nearby branch to assess the situation, and then darted in, grabbed a seed, and shot away to hammer off the shell in the safety of a tall tree.

The next year they were joined by a smaller colleague (their offspring, we assumed), a remarkably dumb little bird we named Bonzo in honour of his clowning. Bonzo would perch on people's toques, fly up their sleeves, or hang underneath a hand that held food, pecking at knuckles and fingernails and asking bitterly where we had hidden the damned seeds!

Numbers grew; soon we had a regular winter flock of greedy and indistinguishable birds that would 
pursue guests from their cars to the door of the house demanding seeds. Charming though they seem to us, chickadees are aggressive and belligerent little birds with each other, and when one tiny bird appeared with his head bleeding and pecked bare of feathers, we suspected he had tried to push his way too far into the lineup for the feeder, and had paid a high price for his foolishness. We called him Ratbag, for he truly looked gnawed. He survived his mauling and, bellicose bird that he was, quickly became dominant in the flock - first to the feeder, first to the hand, full of feather-puffing and warcries when another bird got too close. In time he grew brave enough to take a seed delicately from between my lips. The feathers on his head grew back, but he was marked forever with one tiny patch of white in his black cap. Being able to recognize an individual bird piqued our curiosity; we began to wonder about who is paired to whom, and how long does it last, and what about children? I mean, for all we knew we might have something more exciting than the afternoon Soaps, if we could just tell one bird from another. And just how many chickadees do we have? (There seem to be dozens, to judge by the rate at which they come and go.)

Having spent several summers assisting Stuart Houston in his raptorbanding research, I have a banding license, and applied for a special permit to put coloured bands on our local chickadees. Two afternoons was all it took to trap each of the birds in our flock in a wire cage trap atop the feeding platform, fitting each chickadee with a numbered aluminum band and two of coloured plastic. The trapping and banding didn't seem to traumatize them: they were back at the feeder within minutes of being released. First caught, and rewarded with two white bands, was of course - Ratbag. Rechristened White White, he remained Top Bird until the spring of his fifth year (a Methuselah among chickadees!), when Red/Red, the toughest fledgling of the previous year, began to muscle in at the feeder. Ratbag disappeared in the Fall. Red/Red vanished early this summer. It's been nice to know our birds as individuals, but a little sad, too.

So what have we learned in three years of banding? Well, our initial guess of "dozens" of birds was exaggerated. We had precisely 11 chickadees that first autumn, and though we banded 18 birds over the next two years it appears that the population using our feeder generally hovers around 12, with half the new fledglings moving off to new territory in the late fall, and one or two unbanded birds joining ours during the winter. Do mated pairs stay together more than one season? In one case, yes; in three cases, no.

The flock stays together through the winter, but when mating season arrives they disperse. The dominant bird and his/her mate (how do you determine the sex of a chickadee?) remain "in possession" of the feeder, though sometimes a second pair will feed when the owners are out of sight. In the fall everybody blends back into one flock, with the newly banded youngsters waiting their turn for the adults at the feeder. The pushiest youngster, however, seems destined to be Number One Chickadee in a year or two. About half the young birds have vanished from our feeder by the end of their first winter, some to set up on new territory, but doubtless some succumb to bad weather, poor food supplies, and predators. The remaining birds 
generally seem to survive for two to three years. One year we thought we'd lost all "our" birds, but later discovered that a neighbour had accidentally spilled a huge bag of sunflower seeds on the ground by his barn. When they had grazed out the pastures of plenty, the flock of fat little chickadees returned to our more modest feeding station. Last December, however, when we had a sudden and very nasty two weeks of bitter weather, only four of our regular 10 birds continued to appear at the feeder. Did the others perish? We don't know; little birds are rarely noticed when they die, so very few re- covered bands are returned to the Banding Office in Washington. The farthest afield that our banded birds have been sighted - and reported to us - is about a mile. But there's more to learn, so keep your eyes open: if you see a banded chickadee at your feeder note the colours, and which leg they're on. Stuart Houston has banded a number of chickadees in his Saskatoon neighbourhood, but there's no duplication in colours between his birds and ours. [Call us if you see a banded bird - 374-9176. We'll find out where "our" chickadees are going, and you'll learn a bit about where "yours" have come from.]

\section{MYSTERY BIRD}

Let me have your suggestions on the identity of this albino bird. You are welcome to phone me at 652 5268 , or e-mail at minke@link.ca, or by mail c/o Nature Saskatchewan. The results (consensus?) will be published in a future issue.

By direct comparison to the Evening Grosbeak and Dark-eyed

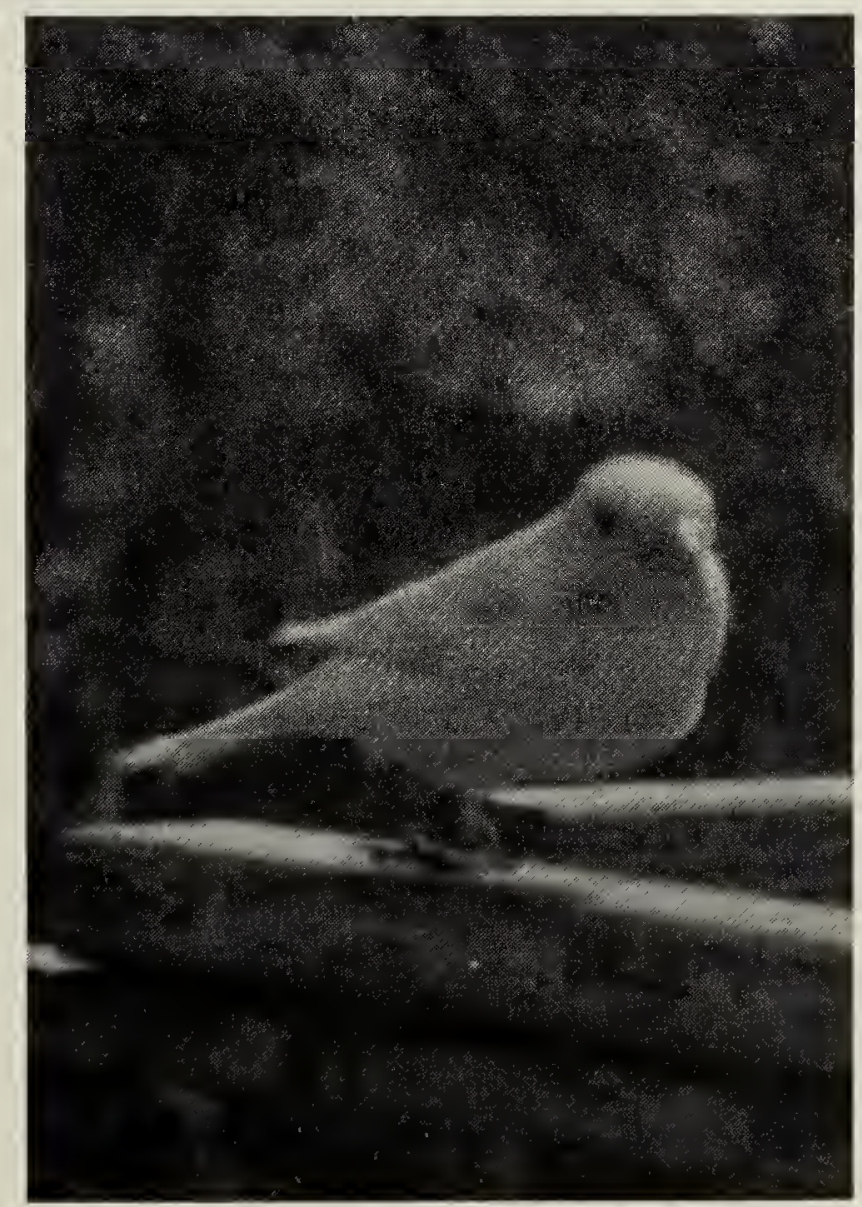

Junco, the bird is estimated to be around $71 / 4^{\prime \prime}$ long. On other photos it shows a flattish head with the eye closer to the base of the bill than the rear of the head. It has a broadbased conical bill. The tail is squarish at the end, with a slight notch. It was seen at Beth Dale's feeder on Murphy Lake, near Loon Lake, SK.

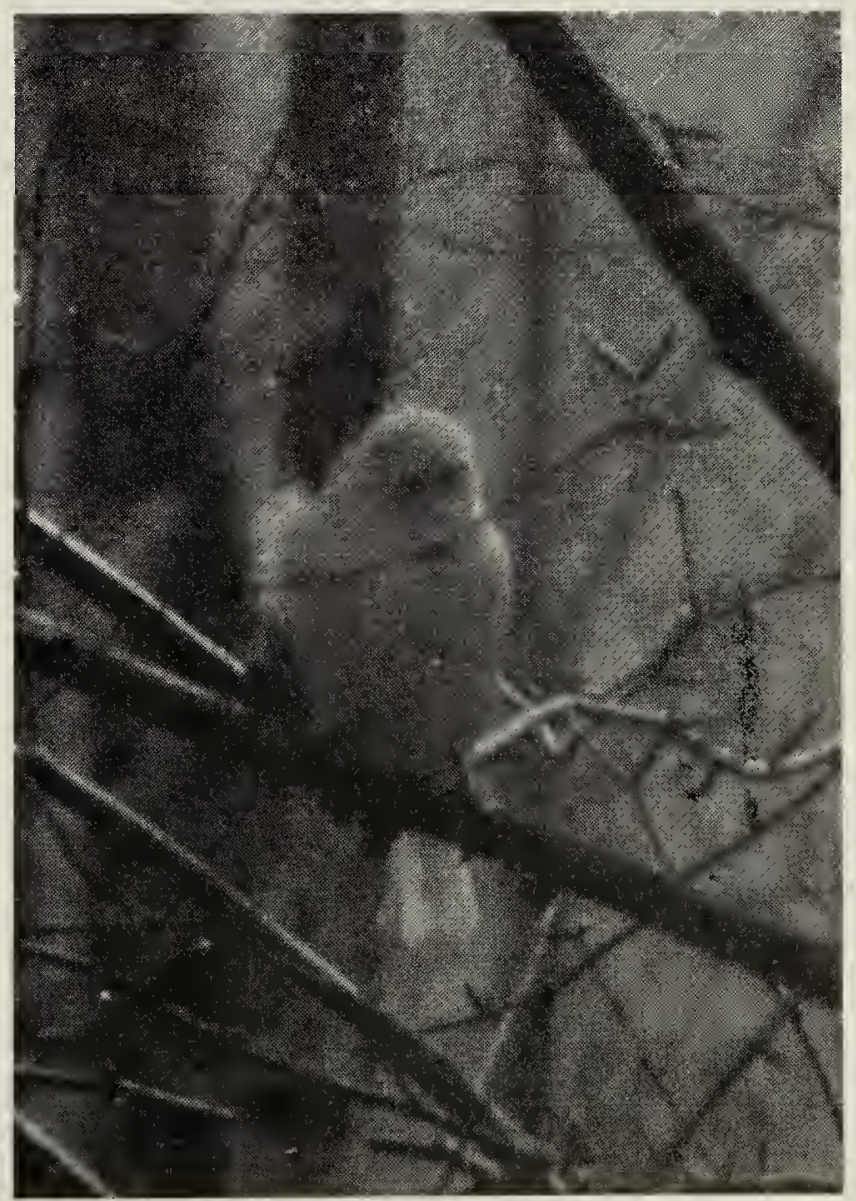

